\title{
Determinant Factors' Impact on Managerial Performance through Management Accounting Systems in Indonesia*
}

\author{
Luk Luk FUADAH ${ }^{1}$, Rika Henda SAFITRI ${ }^{2}$, Yuliani YULIANI ${ }^{3}$, Anton ARISMAN ${ }^{4}$ \\ Received: July 18, 2020 Revised: August 23, 2020 Accepted: August 28, 2020
}

\begin{abstract}
This study aims to examine the effects of factors related to management accounting systems and managerial performance. The factors include budgetary participation, decentralization, and management style. Furthermore, this research investigates the consequences of the management accounting systems on managerial performance and the direct effect between management style and budgetary participation on managerial performance. Survey questionnaires were distributed to both public and private hospitals in Palembang, the South Sumatera region, Indonesia. The sample consisted of 62 respondents from 15 hospitals Target respondents were all managers in hospitals, including financial managers, service managers, human resource managers, quality managers, and other managers. The questionnaire was distributed online to each hospital, and approximately five or more questionnaires were hardcopies. This research was conducted over less than six months. The data obtained were processed via excel files, then checked for conformity, and analyzed by partial least square (PLS) software with descriptive statistics. This study uses path analysis, which that is structural equation modeling (SEM). The findings show that management style, decentralization, and budgetary participation significantly affect management accounting systems. However, management style and budgetary participation did not influence managerial performance. Finally, the findings indicate that management accounting systems are positively affected by managerial performance.
\end{abstract}

Keywords: Budgetary Participation, Management Style, Decentralization, Management Accounting Systems, Managerial Performance

JEL Classification Code: I18, L21, M41, M49

\section{Introduction}

The accounting system must fulfill three objectives, namely, improves cost efficiency within hospitals without compromising the quality of institutional services, allows hospitals to maximize their resources through service line

\section{*Acknowledgements:}

This research is supported by the grant for the research from Universitas Sriwijaya.

${ }^{1}$ First Author. Associate Professor, Department of Accounting, Faculty of Economics, Universitas Sriwijaya, Indonesia. Email: lukluk_fuadah@unsri.ac.id

${ }^{2}$ Assistant Professor, Department of Accounting, Faculty of Economics, Universitas Sriwijaya, Indonesia. Email: rikahenda@unsri.ac.id

${ }^{3}$ Associate Professor, Department of Management, Faculty of Economics, Universitas Sriwijaya, Indonesia.

Email: yulianisyapril@unsri.ac.id

${ }^{4}$ Corresponding Author. Assistant Professor, Department of Accounting, Sekolah Tinggi Ilmu Ekonomi Multi Data Palembang, Indonesia [Postal Address: STIE MDP Palembang, JI. Rajawali No. 14, Palembang, 30113, Indonesia] Email: ariman@stie-mdp.ac.id

(c) Copyright: The Author(s)

This is an Open Access article distributed under the terms of the Creative Commons Attribution Non-Commercial License (https://creativecommons.org/licenses/by-nc/4.0/) which permits unrestricted non-commercial use, distribution, and reproduction in any medium, provided the original work is properly cited. management, and highlights the opportunities for continuous improvement in hospital operations (Ramsey et al., 1994). Based on Chenhall and Morris (1986), management accounting systems consist of four dimensions, namely, integration, aggregation, scope, and timeliness; these are important for the hospital sector. The managers use the management accounting systems to have information and use it for decision-making. This study used four dimensions to investigate the management accounting system in hospitals. This research was conducted at the hospitals to investigate the application of management accounting systems in decision-making related to managerial performance.

Cadez and Guilding (2008)market orientation, and company size on two distinct dimensions of strategic management accounting (SMA suggested that the modern management accounting system is not automatically related to the manager's performance. Manager's performance is one of the contingent factors that can be influenced by the management accounting system. To date, very few studies have empirically tested how the relationship between contextual variables and management accounting systems affects organizational performance or managerial performance in the hospital industry (Abernethy \& Brownell, 1999, Abernethy \& Lillis, 2001). 
Chong and Eggleton (2003) examined the effect of task uncertainty, locus of control, and management accounting systems on managerial performance. Din and Habibullah (2015) looked at budgetary participation in managerial performance through the adoption of performance measurement and management accounting systems. The interaction between budgetary participation and broad scope of management accounting systems effects managerial performance. The adoption of the management accounting system and performance measures on the relationship between budgetary participation and managerial performance in the government organizations in Malaysian was researched by Din and Habibullah (2015).

Previous research related to management styles that affect performance (Ogbonna \& Harris, 2000; Yousef, 2000; Elenkov, 2002; Rowold, 2011). Furthermore, management style positively influences management accounting systems (Naranjo-Gil \& Van Rinsum, 2006). Additionally, managers who use management accounting system information in a wider scope can make more effective managerial decisions to set appropriate targets and evaluate achievements, which in turn increases managerial performance (Gul, 1991; Mia \& Clarke, 1999; Eker, 2009; Tsui, 2001). This research was conducted in several different countries - Russia (Elenkov, 2002); United Kingdom (Ogbonna \& Harris, 2000); Germany (Rowold, 2011); Spain's Andalucia (Eker, 2009); China (Tsui, 2001); Australia (Naranjo-Gil \& Van Rinsum, 2006; Mia \& Clarke, 1999); United Emirates Arab (Yousef, 2000). This research is different from previous studies in that it empirically tested the propositions through surveys in hospitals in Palembang, South Sumatera, Indonesia. This study focuses on testing and analyzing budgetary participation, decentralization, and management style on managerial performance through management accounting systems.

The main objective of this study is to test empirically the interaction between several factors such as management style, budgetary participation, and decentralization effect on management accounting systems, and managerial performance. The secondary objective is to understand the influence, both direct and indirect, of the management style, budgetary participation, and decentralization on managerial performance through management accounting systems.

Most of the prior research investigates the management accounting systems in manufacturing companies. This study investigates and gives empirical evidence on management accounting systems in service companies such as hospitals. This study is the first effort to investigate the determinant factors on management accounting systems that have been ignored by previous studies, especially in the emerging Asian markets. This study contributes in two areas. Firstly, its findings on determinant factors can be used by hospitals, especially in Indonesia, as a reference in designing policies concerning the management accounting systems. Secondly, the findings on the relationship between management accounting systems and managerial performance can be used by hospitals in formulating strategies

Several contributions from this study are expected. First, this is the first study to combine the concept of management accounting systems, management style, budgeting participation, decentralization, and managerial performance; the framework tested in this study is more comprehensive. Second, this study adds to the research findings in the Indonesian context, especially examination of the management accounting systems and company services especially at hospitals.

\section{Literature Review}

\subsection{Contingency Theory}

Contingency theory reveals that design and use of accounting system that can be applied to all organizations. The contingency theory also reveals use of control systems depends on the organizational context in which these controls operate and function properly (Otley, 1980). Management accounting systems can apply to all types of organizations following the activities of the organization in dealing with all situations (Otley, 2016). With the existence of an accounting system, if there is participation in preparing the budget, the organization can improve its performance. In line with this theory, this current research aims to investigate how contextual variables, such as budgetary participation, management style, and decentralization on management accounting system, these characteristics, in turn, affect managerial performance in hospitals at South Sumatera, Palembang, Indonesia.

\subsection{Previous Research}

Chung et al. (2012) revealed the effect of management accounting systems on the performance of managers with ambiguity in the role of mediation. The results show that the ambiguity of the squeeze mediates the effect of the management accounting system on the manager's performance. Cheng (2012) conducted a study on managers at Taiwanese electronics companies. The results showed that budgetary participation affected the performance of managers through the scope of the management accounting system. Hammad et al. (2013) conducted a study at hospitals in Egypt. The results showed that environmental uncertainty and decentralization affect the performance of managers through management accounting systems (Hammad et al. 2013).

Gurendrawati and Murdayanti (2015) examined the effects of use of communication technology, management accounting systems, and locus of control on the performance 
of managers in telecommunication companies in Indonesia. Research on regional work units in Aceh shows that budgetary participation influences the managers's performance through management accounting systems (Indriani \& Nadirsyah, 2015). From their research on the Malaysian government, Din and Habibullah (2015) examined the effect of budgetary participation on the managers' performance through the adoption of performance measurement and management accounting systems. Their results show that the adoption of performance measurement and management accounting systems mediates the effect between budgetary participation and manager's performance.

Ghasemi et al. (2016) examined the competition affecting the performance of managers through management accounting systems in financial organizations in Iran. This research reveals that internal and environmental factors influence performance (Ghasemi et al., 2016). Budgetary participation at government in Indonesia (Jatmiko et al. 2020). Nguyen et al. (2020) examined factors influence on management accounting in Vietnam.

\subsection{Theoretical Model and Hypotheses}

The relationship between budgetary participation and management accounting systems has been identified to be positive (Etemadi et al., 2009; Eker, 2009; Cheng, 2012; Din \& Habibullah, 2015). The resulting research from Eker (2009) shows the influence between budgetary participation and management accounting systems. However, Tsui, (2001), surveying Chinese managers, states that the relationship between budgetary participation and management accounting systems is negative. Thus, the hypothesis can be stated as follow:

H1: Budgetary participation has a positive effect on management accounting systems.

Abdel-Kader and Luther (2008), Soobaroyen and Poorundersing (2008) and Stergiou et al. (2013) reveal the positive impact of decentralization and management accounting systems with sufficient relevant information on controlling and decision-making. Thus, as firms expand, there is a need for more formal planning and control system through a decentralized structure (Hoque, 2011, Stergiou et al., 2013). Thus, the second hypothesis can be stated as follow:

H2: Decentralization has a positive impact on management accounting systems.

An important issue related to management style is the extent to which managers are involved in the collection of relevant information to optimize their decision-making
(Dean \& Sharfman, 1996). Management style influences the achievement of organizational goals through organizing, leading, and controlling organizational resources (Simons, 1990). Management style has a positive effect on management accounting systems (Naranjo-Gil \& Van Rinsum, 2006). The hypothesis can be stated as follow:

H3: Management style has a positive effect on management accounting systems.

There is a direct influence of budgetary participation on managerial performance. Derfuss (2009) found that budgetary participation has a positive and significant impact on managerial performance. Furthermore, Gurendrawati and Murdayanti (2015), Chong and Mahama (2014) indicate that budgetary participation and managerial performance have a positive link. Budgetary participation has a positive impact on managerial performance (Eker, 2009; Cheng 2012). Furthermore, budgetary participation does not affect managerial performance (Parsian, 2015). Below is the following hypothesis:

H4: Budgetary participation has a positive influence on managerial performance.

Previous studies have examined management styles that affect performance (Ogbonna \& Harris, 2000; Yousef, 2000; Elenkov, 2002; Rowold, 2011). This research was carried out in several countries such as United Kingdom Russia (Elenkov, 2002), United Kingdom (Ogbonna \& Harris, 2000), Germany (Rowold, 2011), and the United Emirates Arab (Yousef, 2000). Below is the following hypothesis:

H5: Management style has a positive effect on managerial performance.

As regards the relationship between the use of management accounting systems and managerial performance, according to Chong (1996), the managerial performance was high when a broad scope of management accounting system information was used by managers. Soobaroyen and Poorundersing (2008) revealed that the management accounting systems have a positive and significant impact on managerial performance. It is concluded that all management accounting systems' dimensions are conclusively related to managerial performance (Chia, 1995; Bouwens \& Abernethy, 2000; Soobaroyen \& Poorundersing, 2008; Eker, 2009; Etemadi et al., 2009). The results showed that management accounting systems, for all characteristics including broad scope, timeliness, aggregation, and integration, have a positive influence on managerial performance (Mia \& Clarke, 1999; Soobaroyen \& Poorundersing, 2008). The characteristics of management accounting systems such as broad scope and 
timeliness have an impact on managerial performance (Tsui, 2001; Eker, 2009; Etemadi et al., 2009). Furthermore, the characteristics include broad scope influence on managerial performance (Cheng, 2012). However, Chung et al., (2012) reveal that a broad scope of management accounting systems does not influence managerial performance. The hypothesis is stated as follow:

H6: The management accounting system has a positive influence on managerial performance.

\section{Methodology}

\subsection{Sample}

This research focuses on hospitals in the city of Palembang, South Sumatra, Indonesia. This sample is drawn from all hospitals in Palembang, both public and private. The population in this study is the managers at the hospitals, such as financial managers, services managers, quality manager, human resources managers, and other managers. This study uses a saturated sample that is all the population taken as a sample. This research uses primary data collected via a questionnaire survey.

\subsection{Measurement}

The instrument in the variables of this study is divided into two parts. The first section included demographics questions about the respondents like gender, age, academic level, and department work in their companies. The second section included questions based on the variables in this study. This research instrument was adopted from previous research. To measure budgetary participation variables, we used instruments adopted from Brownell (1983) with a total of six questions. Budgetary participation shows the involvement of individuals in the budgeting process within a company or organization (Brownell, 1983).

Management styles are classified as a proactive or reactive style of managers. The proactive management style is defined as a democratic style that is participatory, oriented towards the future and the external environment, including extensive planning, with managers looking for possibilities for coordination and synergy between departments and re-evaluating organizational goals. However, the reactive management style is more autocratic, focuses more on individual goals and expectations rather than organizational goals, and focuses more on controlling measurable quantitative events within the organization (Larson et al., 1986). Management style was assessed (Larson et al., 1986) with a total of five questions.

Decentralization refers to the level of autonomy delegated by managers or superior to lower-level unit managers (Libby $\&$ Waterhouse, 1996). Authority is an action taken related to decisions without waiting for confirmation from superiors (Hoque, 2011). The measurement of decentralization is assessed based on Libby \& Waterhouse (1996) with a total of six questions. The sum of the values assigned to each company policy in the list was used to indicate the level of delegation of authority in the company's sample (Libby \& Waterhouse, 1996).

Management accounting system is a system that collects financial and operational data, processes, stores and reports them to users, both employees and managers or executives (Chenhall \& Morris, 1986). The management accounting system was examined based from Chenhall and Morris (1986) with a total of ten questions.

Managerial performance is a series of achievement of tasks performed by a manager. Mahoney, Jerdee, \& Carroll, (1965) stated that the role of the manager is a series of functions that cover all management performance that must have definitions and relationships that are integrated with one another. Furthermore, Mahoney et al. (1965) revealed that the manager's performance consists of the manager's planning, investigating, coordinating, evaluating, supervising and supervising functions, negotiating and representing. To measure managerial performance we adopted the concept of Mahoney et al. (1965) with a total of eight questions.

\subsection{Analysis Tools}

To test the hypotheses, this study uses Partial Least Square (PLS). Ali et al. (2020) and Saleh et al. (2020) use the PLS in their analysis. SEM generally has third characteristics. First, it estimates whether relationships are diverse and equally related. Second, it estimates whether the relationships are diverse and interrelated. The third is the capacity to illustrate concepts that cannot be considered in the framework of this relation or relationship. Furthermore, this analysis will examine the error measurement in the estimation process (Hair et al., 2010). The model is presented below in the form of an equation:

$$
\begin{aligned}
& \mathrm{SAM}=\beta_{0}+\beta_{1} \mathrm{X}_{1}+\beta_{2} \mathrm{X}_{2}+\beta_{3} \mathrm{X}_{3}+\varepsilon \\
& \mathrm{MP}=\beta_{0}+\beta_{1} \mathrm{X}_{1}+\beta_{2} \mathrm{X}_{2}+\beta_{1} \mathrm{SAM}_{1}+\varepsilon
\end{aligned}
$$

Where: $\mathrm{MP}=$ Managerial Performance; $\mathrm{SAM}=$ Management Accounting Systems; $X_{1}=$ Budgetary performance; $\mathrm{X}_{2}=$ Management Style; $\mathrm{X}_{3}=$ Decentralization; $\alpha=$ Constant; $\beta 1=$ Regression Coefficient; $\varepsilon=$ Standard Error

\section{Results}

Table 1 shows the descriptive statistic for all variables. All indicators of the variables from our model research are reliable and valid (Table 2 and Table 3). We then assess the results of the structural model and test the hypotheses. 
Table 1: Descriptive Statistic

\begin{tabular}{|l|c|c|c|c|c|}
\hline Construct & N & Min & Max & Mean & Standard Deviation \\
\hline Budgetary Participation & 62 & 1 & 7 & 4,02 & 2,076 \\
\hline Decentralization & 62 & 1 & 7 & 3,23 & 1,859 \\
\hline Management Style & 62 & 1 & 7 & 5,26 & 1,708 \\
\hline Management Accounting System & 62 & 1 & 7 & 4,90 & 1,479 \\
\hline Managerial Performance & 62 & 1 & 7 & 5,16 & 1,549 \\
\hline
\end{tabular}

Table 2: The Validity and Reliability of the Measurement Model

\begin{tabular}{|l|c|c|c|c|}
\hline Constructs & Cronbach's Alpha & Rho-A & CR & AVE \\
\hline Budgetary participation & 0,955 & 0.964 & 0,905 & 0.818 \\
\hline Management Style & 0,922 & 0.941 & 0,874 & 0.763 \\
\hline Decentralization & 0,941 & 0.954 & 0,880 & 0.775 \\
\hline Management Accounting System & 0,976 & 0.978 & 0,836 & 0.699 \\
\hline Manager Performance & 0,965 & 0.970 & 0,896 & 0.802 \\
\hline
\end{tabular}

Table 3: Structural model results

\begin{tabular}{|l|c|c|c|c|c|c|}
\hline Construct & Adj. $\mathbf{R}^{\mathbf{2}}$ & $\mathbf{F}^{2}$ & $\mathbf{Q}^{2}$ & VIF & SRMR & NFI \\
\hline Budgetary Participation & & $1.374-1.807$ & & 2.281 & & \\
\hline Decentralization & & 1.921 & & 2.252 & & \\
\hline Management Style & & $1.127-1.228$ & & 1.289 & & \\
\hline Management Acc. System & 0.436 & 1.624 & 0.433 & & 0.071 & 0.970 \\
\hline
\end{tabular}

Table 4: The Result of Hypotheses

\begin{tabular}{|l|c|c|c|}
\hline Hypothesis & Coefficient $(\boldsymbol{\beta})$ & P-Values & Result \\
\hline $\mathrm{PA} \rightarrow \mathrm{SAM}(\mathrm{H} 1)$ & 0,32 & 0,01 & Supported \\
\hline DSentral $\rightarrow$ SAM $(\mathrm{H} 2)$ & 0,21 & 0,05 & Supported \\
\hline $\mathrm{GK} \rightarrow \mathrm{SAM}(\mathrm{H} 3)$ & 0,32 & 0,01 & Supported \\
\hline $\mathrm{PA} \rightarrow \mathrm{KM}(\mathrm{H} 4)$ & 0,38 & $-0,05$ & Rejected \\
\hline $\mathrm{GK} \rightarrow \mathrm{KM}(\mathrm{H} 5)$ & 0,01 & 0,44 & Rejected \\
\hline $\mathrm{SAM} \rightarrow \mathrm{KM}(\mathrm{H} 6)$ & 0,85 & 0,01 & Supported \\
\hline
\end{tabular}

Note: Significant statistically at 1 percent and 5 percent level

$(\mathrm{PA}=$ Budgetary Participation, Dsentral $=$ Decentralization, $\mathrm{KM}=$ Management Style $; \mathrm{SAM}=$ Management Accounting Systems; $\mathrm{KM}=$ Managerial Performance)

In testing the hypotheses above the coefficient parameters and significant values were generated with the bias confidence interval corrected by $95 \%$ of each independent variable. From Figure 1 and Table 4, we can see the results for all hypotheses proposed in this study. All proposed hypotheses show a positive effect. However, hypothesis 4 and 5 ( $\mathrm{H} 4$ and $\mathrm{H} 5)$ were not supported. 


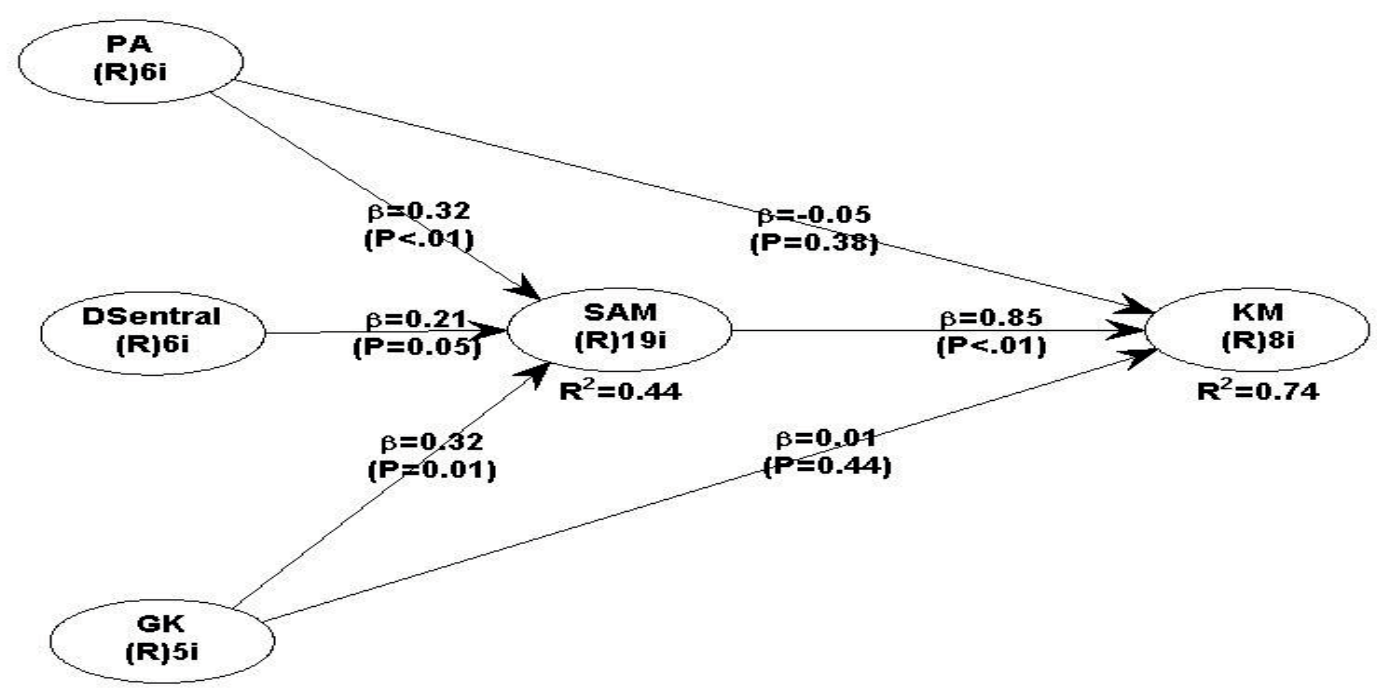

Figure 1: The Result Research

\section{Discussion}

Hypothesis 1 states that budgetary participation has a positive effect on management accounting systems. The results of this study support the contingency theory, according to which management accounting systems can be applied in an organization in dealing with situations outside the company. There is no accounting system that can apply to the entire organization, so every organization must create a certain management accounting system that can be run following the activities in the organization in order to deal with all situations that will later relate to the organization. This study also supports previous research. Cheng (2012) shows that budgetary participation influences the management accounting system. However, the management accounting system used in his research is only based on the characteristics of the broad scope of management accounting system (Cheng, 2012). This study uses all characteristics, including timeliness, aggregation, integration, and broad scope for management accounting systems.

Hypothesis 2 states that decentralization has a positive impact on management accounting systems, which have been empirically accepted. Thus, the results of hypothesis testing indicate that the higher the decentralization, the more likely companies are to implement a management accounting system. This finding supports the contingency theory, which states that decentralization is related to the characteristics of management control systems (Chenhall, 2003). Decentralization also gives managers more responsibility and control in their activities and requires greater information as well (Waterhouse \& Tjessen, 1978). Thus, it can be concluded that, with decentralization, information is needed in decision-making. This shows that there is a need for a more complete management accounting control system that provides relevant information at a high level of decentralization. The results of this study are in line with several previous researchers (Hoque, 2011; Stergiou et al., 2013).

Hypothesis 3 states that management style has a positive effect on management accounting systems. Management style is a contingency variable that shows the degree of organizational formality, the management process of management, the precise motivational process, the degree of participation, and the level at which decisions are made (Larson et al., 1986). Management style influences the achievement of organizational goals through organizing, leading, and controlling organizational resources (Simons, 1995). Thus, the results of hypothesis testing indicate that the higher the management style, the more likely companies are to implement a management accounting system. This finding supports Naranjo-Gil and Van Rinsum (2006) who posited that management style influences management accounting systems.

Hypothesis 4 states that budgetary participation has a positive influence on managerial performance. The results of the study provide empirical evidence that leads to reject H4. The result of this study does not support other research such as (Eker, 2009; Cheng 2012). This finding is in line with other research that reveals that budgetary participation does not affect managerial performance (Parsian, 2015).

Hypothesis 5 states that management style has a positive influence on managerial performance. The study shows empirical evidence leading to the rejection of $\mathrm{H} 5$. The results of this study do not support previous research (Ogbonna \& Harris, 2000; Yousef, 2000; Elenkov, 2002; Rowold, 2011) which states that management style influences the performance. 
Hypothesis 6 states that the management accounting system has a positive effect on management performance. The results of this research with empirical evidence indicate that H6 is accepted. This means that the management accounting system is high, so the manager's performance has also increased. This study also supports previous research (Chia, 1995; Bouwens \& Abernethy, 2000; Soobaroyen \& Poorundersing, 2008; Eker, 2009; Etemadi et al., 2009). The results showed that management accounting systems with all their characteristics including broad scope, timeliness, aggregation, and integration, have a positive influence on managerial performance (Mia \& Clarke, 1999, Soobaroyen $\&$ Poorundersing, 2008). The characteristics of management accounting systems such as broad scope and timeliness have an impact on managerial performance (Tsui, 2001; Eker, 2009, Etemadi et al., 2009). Furthermore, the characteristics include broad scope influence on managerial performance (Cheng, 2012).

\section{Conclusions}

This study results do not support the concept of direct impact. First, the direct effect of budgetary participation and management style on managers' performance shows insignificant effects. Budgetary participation has a negative and not significant effect on managerial performance. This indicates that the higher the budgetary participation, the lower the manager's performance and vice versa. Management style has no significant effect on managerial performance.

However, the indirect effect of budgetary participation, decentralization, and management style on managerial performance results from the manager's accounting system. The results showed budgetary participation, decentralization, and management style had a positive and significant effect on management accounting systems as well as positive and significant influences on management accounting systems and managerial performance. These empirical results indicate that this management accounting system acts as a mediator between budgetary participation, decentralization, management style, and manager's performance in hospitals in Palembang.

This research has several weaknesses. The first weakness is that this study cannot be generalized to other sectors because it was very limited in its settings, that is, it was conducted in hospitals in Palembang. The second limitation is that this study only examined budgetary participation, decentralization, management style, management accounting systems, and managerial performance. The results show that the coefficient of determination $\left(\mathrm{R}\right.$ square- $\left.\mathrm{R}^{2}\right)$, which indicates the ability to explain the variables, is still low; it means that there are still other variables that have the potentials for further investigation.
This study makes several suggestions for future research. Further investigations should only focus on one sector and be more specific; as an example, it should focus on the financial, manufacturing or mining sector. The next suggestion is to investigate other variables that have not been tested in this study as organizational commitment, corporate governance, technology, and other factors.

\section{References}

Abdel-Kader, M., \& Luther, R. (2008). The impact of firm characteristics on management accounting practices: A UKbased empirical analysis. British Accounting Review, 40(1), 2-27. https://doi.org/10.1016/j.bar.2007.11.003

Abernethy, M. A., \& Brownell, P. (1999). The role of budgets in organizations facing strategic change: An exploratory study. Accounting, Organizations and Society, 24(3), 189-204. https://oi.org/10.1016/S0361-3682(98)00059-2

Abernethy, M. A., \& Lillis, A. M. (2001). Interdependencies in Organization Design: A Test in Hospitals. Journal of Management Accounting Research, 13(1), 107-129.

Ali, Q., Salman, A., Yaacob, H., Zaini, Z., \& Abdullah, R. (2020). Does Big Data Analytics Enhance Sustainability and Financial Performance? The Case of ASEAN Banks. Journal of Asian Finance, Economics and Business, 7(7), 1-13. https://doi. org/10.13106/jafeb.2020.vol7.no7.001

Bouwens, J., \& Abernethy, M. A. (2000). The consequences of customization on management accounting system design. Accounting, Organizations and Society, 25(3), 221-241. https://doi.org/10.1016/S0361-3682(99)00043-4

Brownell, P. (1983). Leadership style, budgetary participation and managerial behavior. Accounting, Organizations and Society, 8(4), 307-321. https://doi.org/10.1016/0361-3682(83)90046-6

Cadez, S., \& Guilding, C. (2008). An exploratory investigation of an integrated contingency model of strategic management accounting. Accounting, Organizations and Society, 33(7-8), 836-863. https://doi.org/10.1016/j.aos.2008.01.003

Cheng, M.-T. (2012). The joint effect of budgetary participation and broad $\square$ scope management accounting systems on management performance. Asian Review of Accounting, 20(3), 184-197. https://doi.org/10.1108/13217341211263256

Cheng, M. (2012). The joint effect of budgetary participation and broad-scope management accounting systems on management performance. Asian Review of Accounting, 20(3), 184-197. https://doi.org/10.1108/13217341211263256

Chenhall, R. H. (2003). Management control sysems design within its organizational context: findings from contigency based research and directions for the future. Accounting, Organizations \& Society, 28, 127-168. https://doi.org/10.1063/1.5024417

Chenhall, R. H., \& Morris, D. (1986). The Impact of Structure, Environment, and Interdependence on the Perceived Usefulness of Management Accounting Systems. The Accounting Review, 61(1), 16-35. 
Chia, Y. M. (1995). Decentralization, Management Accounting System (MAS) Information Characteristics and Their Interaction Effects on Managerial Performance: A Singapore Study. Journal of Business Finance and Accounting, 22(February 1994), 811-831.

Chong, K. M., \& Mahama, H. (2014). The impact of interactive and diagnostic uses of budgets on team effectiveness. Management Accounting Research, 25(3), 206-222. https:// doi.org/10.1016/j.mar.2013.10.008

Chong, V. K. (1996). Management Accounting Systems, Task Uncertainty and Managerial Performance: A Research Note. Accounting, Organizations \& Society, 21(5), 415-421.

Chong, V. K., \& Eggleton, I. R. C. (2003). The decision-facilitating role of management accounting systems on managerial performance: The influence of locus of control and task uncertainty. Advances in Accounting, 20(03), 165-197. https:// doi.org/10.1016/S0882-6110(03)20008-0

Chung, S.-H., Su, Y.-F., \& Su, Y.-J. (2012). Broad scope management accounting system and managerial performance : The impact of role ambiguity and functional difference. African Journal of Business Management, 6(30), 8873-8878. https:// doi.org/10.5897/AJBM11.2181

Dean, J. W., \& Sharfman, M. P. (1996). Does decision process matter? A study of strategic decision-making effectiveness. Academy of Management Journal, 39(2), 368-396.

Din, B. H., \& Habibullah, M. S. (2015). The adoption of performance measures and management accounting system in enhancing managerial performance in Malaysian local government. Malaysian Journal of Society and Space, 11(13), 24-35.

Eker, M. (2009). Management Accounting Systems on Performance of Turkish Middle Level Managers. Akdeniz, (17), 105-126.

Elenkov, D. S. (2002). Effects of leadership on organizational performance in Russian companies. Journal of Business Research, 55(6), 467-480. https://doi.org/10.1016/S01482963(00)00174-0

Etemadi, H., Dilami, Z. D., Bazaz, M. S., \& Parameswaran, R. (2009). Culture, management accounting and managerial performance: Focus Iran. Advances in Accounting, 25(2), 216225. https://doi.org/10.1016/j.adiac.2009.08.005

Ghasemi, R., Mohamad, N. A., Karami, M., \& Bajuri, N. H. (2016). The Mediating Effect of Management Accounting System on the Relationship between Competition and Managerial Performance. International Journal of Accounting and Information Management, 24(3), 1-28.

Gul, F. (1991). The Effects of Management Accounting Systems and Environmental Uncertainty on Small Business Managers' Performance. Accounting \& Business Research, 22(85), 57-61. https://doi.org/10.1080/00014788.1991.9729418

Gurendrawati, E., \& Murdayanti, Y. (2015). The Impact Of Information Technology, Management Accounting System Characteristics, and Locus Of Control To The Managerial Performance In The. Review of Integrative Business \& Economics, 4(1), 357-366.
Hair, J. F., Black, W. C., Babin, B. J., \& Anderson, R. E. (2010). Multivariate Data Analysis. Pearson Publisher. https://doi. org/10.1016/j.ijpharm.2011.02.019

Hammad, S., Jusoh, R., \& Ghozali, I. (2013). Decentralization, perceived environmental uncertainty, managerial performance and management accounting system information in Egyptian hospitals. International Journal of Accounting \& Information Management, 21(4), 314-330. https://doi.org/10.1108/ IJAIM-02-2012-0005

Hoque, Z. (2011). The relations among competition, delegation, management accounting systems change and performance : A path model. Advances in Accounting, Incorporating Advances in International Accounting, 27(2), 266-277. https://doi. org/10.1016/j.adiac.2011.05.006

Indriani, M., \& Nadirsyah. (2015). Interaction Effect of Budgetary Participation and Management Accounting System on Managerial Performance: Evidence from Indonesia. Global Journal of Business Research, 9(1), 1-13.

Jatmiko, B., Laras, T., \& Rohmawati, A. (2020). Budgetary Participation, Organizational Commitment, and Performance of Local Government Apparatuses. Journal of Asian Finance, Economics and Business, 7(7), 379-390. https://doi. org/10.13106/jafeb.2020.vol7.no7.379

Larson, L. L., Bussom, R. S., Vigars, W., \& Jauch, L. (1986). Proactive Versus Reactive Manager: Is the Dichotomy Realistic? Journal of Management Studies, 23(4), 385-400.

Libby, T., \& Waterhouse, J. H. (1996). Predicting Change in Management Accounting Systems. JMAR, 8, 137-150.

Mahoney, T. A., Jerdee, T. H., \& Carroll, S. J. (1965). The Job ( s ) of Management. Journal of Management, 97-110.

Mia, L., \& Clarke, B. (1999). Market competition, management accounting systems and business unit performance. Management Accounting Research, 10, 137-158.

Naranjo-Gil, D., \& Van Rinsum, M. (2006). The Effect of Management Style and Management Accounting System Design on Performance. Jamar, 4(1).

Nguyen, H. Q., Thi, O., \& Le, T. (2020). Factors Affecting the Intention to Apply Management Accounting in Enterprises in Vietnam *. Journal of Asian Finance, Economics and Business, 7(6), 95-107. https://doi.org/10.13106/jafeb.2020.vol7. no6.095

Ogbonna, E., \& Harris, L. C. (2000). Leadership style, organizational culture and performance: Empirical evidence from UK companies. International Journal of Human Resource Management, 11(4), 766-788. https://doi. org/10.1080/09585190050075114

Otley, D. (2016). The contingency theory of management accounting and control: 1980-2014. Management Accounting Research, 1-18. https://doi.org/10.1016/j.mar.2016.02.001

Otley, D. T. (1980). The contingency theory of management accounting: Achievement and prognosis. Accounting, Organizations and Society, 5(4), 413-428. https://doi. org/10.1016/0361-3682(80)90040-9 
Parsian, H. (2015). Budgetary participation and managerial performance: The impact of information and environmental volatility Budgetary participation and managerial performance : The impact of information and environmental volatility. Management Science Letters, (July), 843-854. https://doi. org/10.5267/j.msl.2015.7.001

Ramsey, S. L., Lord, C. G., Wallace, D. S., \& Pugh, M. A. (1994). The role of subtypes in attitudes towards superordinate social categories. British Journal of Social Psychology, 33(4), 387-403. https://doi.org/10.1111/j.2044-8309.1994.tb01036.x

Rowold, J. (2011). Relationship between leadership behaviors and performance: The moderating role of a work team's level of age, gender, and cultural heterogeneity. Leadership and Organization Development Journal, 32(6), 628-647. https:// doi.org/10.1108/01437731111161094

Saleh, C., Hayat, H., Sumartono, S., \& Pratiwi, R. N. (2020). Moderating of Religiosity on Reward and Engagement: Empirical Study in Indonesia Public Service *. Journal of Asian Finance, Economics and Business, 7(6), 287-296. https://doi. org/10.13106/jafeb.2020.vol7.no6.

Simons, R. (1990). The role of management control systems in creating competitive advantage: New perspectives. Accounting, Organizations and Society, 15(1-2), 127-143. https://doi. org/10.1016/0361-3682(90)90018-P
Simons, R. (1995). Levers of Control. Boston, Massachussets: Harvard Business School Press.

Soobaroyen, T., \& Poorundersing, B. (2008). The effectiveness of management accounting systems. Managerial Auditing Journal, 23(2), 187-219. https://doi.org/10.1108/02686900810839866

Stergiou, K., Ashraf, J., \& Uddin, S. (2013). The role of structure and agency in management accounting control change of a family owned firm: A Greek case study. Critical Perspectives on Accounting, 24(1), 62-73. https://doi.org/10.1016/j. cpa.2012.09.007

Tsui, J. S. L. (2001). The impact of culture on the relationship between budgetary participation, management accounting systems, and managerial performance : An analysis of Chinese and Western managers. The International Journal of Accounting and Business Society, 36, 125-146.

Waterhouse, J. H., \& Tjessen, P. (1978). A Contingency Framework for Management Accounting Systems Research. Accounting, Organizations and Society, 3(1), 65-76.

Yousef, D. A. (2000). Organizational commitment: A mediator of the relationships of leadership behavior with job satisfaction and performance in a non-western country. Journal of Managerial Psychology, 15(1), 6-24. https://doi. org/10.1108/02683940010305270 